\title{
Pengaruh character education training melalui outbound training untuk peningkatan kejujuran dan integritas
}

\author{
Sahril Buchori \\ Bimbingan dan Konseling, Universitas Negeri Makassar \\ Email: buchori_bk@yahoo.co.id \\ Muhammad Ibrahim \\ Bimbingan dan Konseling, Universitas Negeri Makassar \\ Email: muhibrahim@yahoo.co.id \\ Abdul Saman \\ Bimbingan dan Konseling, Universitas Negeri Makassar \\ Email: absan_unm@yahoo.co.id
}

\begin{abstract}
Outbound method is the most effective method to meet the requirements in regarding a training result. The method is effective to build comprehension of a concept and build individual personality such as honesty and integrity. The caracter will continously apply and become a person with a better personality. The research objective is to know the honest and integrity character's description of the awardee of Bidik Misi in Educational Study Faculty of State University of Makassar (FIP UNM) before and after having the CEt through outbound and to know the effect of CEt through outbound in increasing honest and integrity characters of the awardee of Bidik Misi in Educational Study Faculty of State University of Makassar (FIP UNM). The research is a quantitave research, pre-experimental using One-Group Pretest-Postest Design. The findings is Character Education Training (CEt) through Putbound Training is effective to increase the honest and integrity characters of the awardee of Bidik Misi in Educational Study Faculty of State University of Makassar (FIP UNM).
\end{abstract}

Keywords: Outbound; Honesty; Integrity.

\begin{abstract}
Abstrak: Metode outbound merupakan metode yang paling efektif dalam mengakomodasi/kebutuhan tuntutan terhadap hasil suatu pelatihan. Metode ini efektif untuk membangun pemahaman terhadap suatu konsep dan membangun prilaku karakter individu berupa kejujuran dan integritas. Karakter akan tertanam dan akan menjadi pribadi individu yang lebih baik. Penelitian ini bertujuan untuk mengetahui gambaran karakter jujur dan integritas mahasiswa Bidik Misi FIP UNM sebelum dan setelah pemberian CEt melalui outbound dan untuk mengetahui pengaruh CEt melalui outbound dalam meningkatkan karakter jujur dan integritas mahasiswa Bidik Misi FIP UNM. Penelitian ini adalah penelitian kuantitatif, pre-experimental dengan menggunakan OneGroup Pretest-Posttest Design. Hasil penelitian ini adalah Character Education Training (CEt) melalui Outbound Training efektif untuk peningkatan kejujuran dan integritas mahasiswa Bidik Misi FIP UNM.
\end{abstract}

Kata Kunci: Outbound; Kejujuran; Integritas.

Copyright (C) 2016 Universitas Negeri Makassar. This is an open access article under the CC BYNC-ND license (http://creativecommons.org/licenses/by-nc-nd/4.0/). 


\section{PENDAHULUAN}

Peningkatan mutu mahasiswa sangatlah dibutuhkan dalam rangka meningkatkan kualitas pendidikan. Salah satu mutu pendidikan mahasiswa yang utama adalah memiliki kualitas prestasi dan lulusan yang dapat bermanfaat di tengah masyarakat. Lingkungan memiliki peran besar dalam menghasilkan prilaku yang baik, seperti lingkungan akademik. Mutu mahasiswa yang diharapkan yaitu kepatuhan terhadap etika, sikap proaktif mahasiswa dalam proses belajar mengajar, prestasi akademik yang ditunjukkan, dan yang utama adalah kompetensi lulusan yang handal (Tim Pengembang SPMI-PT. 2010).

Mahasiswa sebagai agent of social change (agen perubahan sosial) dan selaku insan akademis, dipandang memiliki kekuatan intelektual yang lebih sehingga kepekaan dan nalar yang rasional diharapkan dapat memberikan kontribusi nyata terhadap pembangunan pendidikan dan sosial dimasyarakat. Oleh karena itu sudah menjadi konsekuensi terhadap tuntutan dari seorang mahasiswa untuk mampu mengoptimalkan potensi yang dimilikinya sebagai suatu kebutuhan pribadi dan masyarakat. (Widia, 2014). Fungsi kontrol sosial yang dimiliki mahasiswa bagi pembangunan diharapkan mutlak demi kemajuan pembangunan.

Peningkatan mutu mahasiswa sangatlah ditentukan oleh karakter yang dimilikinya. Karakter yang penting dimiliki oleh mahasiswa diantaranya memiliki kejujuran dan integritas. Jujur adalah mengakui, berkata atau memberikan suatu informasi yang sesuai kenyataan dan kebenaran. Perilaku jujur juga dapat dipahami tidak hanya sebatas perkataan yang benar saja tapi juga dapat dilihat dari perilaku atau perbuatan yang benar seperti menaati peraturan yang berlaku. Banyak ayat $\mathrm{Al}$ Qur'an menerangkan kedudukan orang-orang jujur antara lain: QS. Ali Imran (3): 15-17, An Nisa' (4): 69, Al Maidah (5): 119. Begitu juga secara gamblang Rasulullah Muhammad Saw menyatakan dalam sabdanya:

Wajib atas kalian untuk jujur, sebab jujur itu akan membawa kebaikan, dan kebaikan akan menunjukkan jalan ke surga, begitu pula seseorang senantiasa jujur dan memperhatikan kejujuran, sehingga akan termaktub di sisi Allah atas kejujurannya. Sebaliknya, janganlah berdusta, sebab dusta akan mengarah pada kejahatan, dan kejahatan akan membewa ke neraka, seseorang yang senantiasa berdusta, dan memperhatikan kedustaannya, sehingga tercatat di sisi Allah sebagai pendusta, (HR. Bukhari-Muslim dari Ibnu Mas'ud).

Dalam praktek dan penerapannya, secara hukum tingkat kejujuran seseorang biasanya dinilai dari ketepatan pengakuan atau apa yang dibicarakan seseorang dengan kebenaran dan kenyataan yang terjadi. Bila berpatokan pada arti kata yang baku dan harafiah maka jika seseorang berkata tidak sesuai dengan kebenaran dan kenyataan atau tidak mengakui suatu hal sesuai yang sebenarnya, orang tersebut sudah dapat dianggap atau dinilai tidak jujur, menipu, mungkir, berbohong, munafik atau lainnya.

Adapun integritas adalah sifat, atau keadaan yang menunjukkan kesatuan yang utuh, berpegang teguh pada prinsip dan kesesuaian antara kata dengan perbuatan. Aryani (2014: 31) menjelaskan bahwa orang yang memiliki integritas adalah orang yang: a) Memiliki komitmen yang tinggi dalam suatu pekerjaan. Artinya bahwa orang yang memiliki komitmen adalah mereka yang menepati janji dan keyakinan diri yang kuat, termasuk untuk tidak menyontek (plagiat), b) Memiliki tanggung jawab. Artinya bahwa orang yang bertanggung jawab adalah mereka yang berani mengambil resiko dan total melakukan sesuatu dengan kemampuan terbaik yang dimilikinya, termasuk bertanggung jawab untuk menyelesaikan soal/tugas dari dosen secara jujur tanpa melakukan plagiat., c) Orang yang memiliki integritas adalah orang yang dapat dipercaya, jujur dan setia. Artinya bahwa seorang yang memliki integritas berarti ia adalah orang sejalan antara kata dan perbuatan, termasuk jujur dalam mengerjakan soal/tugas dari dosen tanpa harus melakukan plagiat., d) Orang yang memiliki integritas adalah orang yang konsisten pada pendirian. Artinya bahwa orang yang konsisten adalah mereka yang tegas pada keputusan dan pendiriannya, dengan melakukan perimbangan yang bijak dalam bertindak dan bertingkah laku.

Jujur dan integritas merupakan dua hal yang tidak dapat dipisahkan. Menurut Kamus Besar Bahasa Indonesia (KBBI), arti kata integritas adalah sifat, atau keadaan yang 
menunjukkan kesatuan yang utuh, berpegang teguh pada prinsip dan kejujuran (satunya kata denan perbuatan). Sementara arti kata jujur sendiri adalah berkata yang benar, tidak berbohong dan tulus. Berdasarkan pengertian tersebut, bisa dikatakan bahwa kejujuran dan integritas adalah dua hal yang saling berkaitan, dan saling melengkapi satu sama lain. Artinya, seorang yang jujur pasti berintegritas, demikian pula sebaliknya.

Mengembangkan berbagai potensi untuk membentuk karakter, salah satunya dapat dilakukan melalui belajar yang berbasis outdoor. Metode outdoor dapat meningkatkan kebersamaan, kesetiakawanan pelajar, serta dapat memberikan inspirasi kepada pembelajar. Hal ini merupakan nilai-nilai karakter pada potensi individu. Perkembangan diri mahasiswa akan tepat dengan adanya wadah untuk implementasi pengembangan karakter yang tepat, (Purwanto, 2008).

Salah satu wadah yang tepat untuk menanamkan dan mengembangkan karakter mahasiswa adalah melalui kegiatan bermain outdoor seperti outbound. Outbound merupakan pelatihan untuk pengembangan diri di dalam tim. Outbound merupakan metode pelatihan untuk pengembangan diri (personal development) dan tim (team development) dalam proses mencari pengalaman melalui kegiatan di alam terbuka. Ancok (2013) menjelaskan outbound merupakan pendidikan melalui kegiatan alam terbuka (outbound training) dilakukan pada tahun 1821 saat didirikannya Round Hund School sebagai tempat dimana orang-orang berkumpul untuk belajar tentang segala hal dengan menggunakan kebebasan arena yang sangat mendukung berjalannya proses belajar. Hasil penelitian bahwa salah satu kegiatan bermain outdoor berupa ice breaking dapat meningkatkan keterampilan sosial siswa diantaranya kejujuran (Bakhtiar, 2015)

Aktifitas outbound dapat menjaga otak agar terus bergerak dalam melaksanakan kegiatan. Adrianus dan Yufiarti (2006:44) mengatakan bahwa "pada kegiatan outbound terdapat unsur-unsur pengembangan kreativitas, komunikasi, mendengarkan efektif, kerjasama, motivasi diri, kompetisi, problem solving dan percaya diri." Melalui pengalaman belajar sistem outbound maka individu akan lebih peka terhadap tugas yang dimilikinya, lebih kreatif serta tertanam nilai-nilai kejujuran. Kejujuran akan terwujud dengan belajar berkompetisi yang tepat sesuai aturan, kepribadian yang termotivasi pada hal yang lebih positif akan tertanam nilai kejujuran yang lebih besar.

Outbound merupakan salah satu metode pembelajaran melalui experiental learning. Bentuk kegiatannya aplikasi game-game yang ringan, setiap game dalam kegiatan outbound mengandung makna yang dalam, filosofis, dan sarat akan pesan-pesan simbolik yang bermanfaat serta membangun karakter ke arah kesuksesan dalam kehidupan, baik kesuksesan di tingkat individu maupun kesuksesan tim/kelompok. Metode outbound merupakan metode yang paling efektif dalam mengakomodasi/kebutuhan tuntutan terhadap hasil suatu pelatihan. metode ini efektif dalam membangun pemahaman terhadap suatu konsep dan membangun prilaku karakter individu. Karakter akan tertanam dan akan menjadi pribadi individu yang lebih baik.

Menurut Gass (1993) (Ancok, 2013: 3) bahwa metode pelatihan dengan cara permainan di alam terbuka yang kemudian dikenal dengan outbound training juga dapat digunakan untuk kepentingan terapi kejiwaan. Aktivitas outbound training dilakukan menggunakan unsur olahraga dan permainan yang cenderung membuat peserta terlibat langsung secara kognitif (pikiran), afektif (emosi) dan psikomotorik (gerakan fisik motorik). Sehingga secara psikologis dapat dijumpai keterangsangan emosi dan fisik motorik pada diri peserta (Ancok, 2013: 6).

Susilo (2005: 15) mengatakan bahwa outbound training bermanfaat dalam membangun kerjasama tim maupun pembentukan sifat sosial yang berperan dalam dukungan sosial.

Kegiatan outbound mempunyai arti kegiatan di luar ruangan tersebut mengandung unsur permainan, edukasi, serta rekreasi. Melalui permainan-permainan ringan yang menarik, peserta dihadapkan pada suatu tantangan untuk dipecahkan secara bersamasama dengan sejenak melepaskan atribut masing-masing. Sehingga diharapkan tercipta suasana keakraban, kebersamaan serta kerjasama tim yang nantinya bermanfaat dalam mengatasi permasalahan yang lebih besar (Umar, 2011).

Oleh karena itu kegiatan outbond training dapat dilakukan dalam bentuk character education training (CEt) di alam 
terbuka dengan memanfaatkan tim melalui kegiatan bersama untuk mengatasi pribadi yang bermasalah baik psikis maupun fisik, berupa meningkatkan sikap jujur dan nilai integritas dalam berperilaku atau beraktivitas.

Berdasarkan latar belakang yang telah dipaparkan, maka yang menjadi tujuan penelitian ini adalah untuk mengetahui gambaran karakter jujur dan integritas mahasiswa Bidik Misi FIP UNM sebelum dan sesudah pemberian CEt melalui outbound dan untuk mengetahui pengaruh $\mathrm{CEt}$ melalui outbound dalam meningkatkan karakter jujur dan integritas mahasiswa Bidik Misi FIP UNM.

\section{METODE}

Penelitian ini adalah penelitian kuantitatif, pre-experimental yang akan mengkaji tentang pengaruh CEt melalui Outbond training untuk peningkatan kejujuran dan integritas pada mahasiswa Bidik Misi Fakultas Ilmu Pendidikan Universitas Negeri Makassar, angkatan 20132014. Desain penelitian yang digunakan adalah "One-Group Pretest-Posttest Design" (Sugiyono, 2015: 111).

Dalam penelitian ini tidak menggunakan kelompok kontrol. Desain ini dilakukan dengan membandingkan hasil pre-test dengan hasil post-test. Desain yang digunakan dapat digambarkan sebagai berikut :

Tabel 3.1. Model Rancangan Penelitian

\section{$\mathrm{O}_{1} \mathrm{X} \mathrm{O}_{2}$}

Keterangan :

O1 : Pengukuran pertama sebelum subjek diberi perlakuan (Pretest)

$\mathrm{X}$ : Treatment atau perlakuan (CEt melalui Outbound)

$\mathrm{O}_{2}$ : Pengukuran kedua setelah subjek diberi perlakuan (Posttest)

Batasan-batasan variable-variabel yang dikaji dalam penelitian ini sebagai berikut: 1) Outbound training adalah kegiatan di alam terbuka dengan memanfaatkan tim melalui kegiatan bersama untuk mengatasi pribadi yang bermasalah baik psikis maupun fisik, berupa meningkatkan sikap jujur dan nilai integritas dalam berperilaku atau beraktivitas., 2) Kejujuran adalah mengakui, berkata atau memberikan suatu informasi dan berbuat yang sesuai kenyataan atau sebenarnya, sehingga akan membawa kebaikan dan menjauhkan dari sikap dusta., 3) Integritas adalah sifat, atau keadaan yang menunjukkan kesatuan yang utuh, berpegang teguh pada prinsip dan kesesuaian antara kata dengan perbuatan.

Populasi penelitian ini adalah mahasiswa penerima beasiswa bidik misi FIP UNM Makassar angkatan 2013-2014 yang berjumlah 363 orang dari 7 jurusan/program studi di FIP UNM. Pertimbangan besarnya populasi, maka ditetapkan penarikan sampel sebesar $10 \%$ dari populasi 363 sehingga diperoleh sampel 36 orang. Penarikan sampel sesuai dengan pendapat Arikunto (2002: 112) yaitu: "jika jumlah subjeknya besar dapat diambil antara 10\%-15\% atau 20\%-25\% atau lebih tergantung kemampuan peneliti.

Pengambilan sampel dilakukan secara random sampling sehingga setiap jurusan/prodi memiliki kesempatan yang sama untuk menjadi sampel. Adapun penjabaran sampel tersebut sebagai berikut:

Tabel 3.1. Sampel Penelitian

\begin{tabular}{|c|c|c|}
\hline No & $\begin{array}{ll}\text { Jurusan/Prodi } \\
\end{array}$ & Sampel \\
\hline 1. & Psikologi Pendidikan dan Bimbingan (PPB) & 6 \\
\hline 2. & Pendidikan Luar Biasa (PLB) & 5 \\
\hline 3. & Pendidikan Luar Sekolah (PLS) & 5 \\
\hline 4. & Teknologi Pendidikan (TEKPEND) & 5 \\
\hline 5. & Pendidikan Guru Sekolah Dasar (PGSD) & 5 \\
\hline 6. & Pendidikan Guru Pendidikan Anak Usia Dini (PGPAUD) & 5 \\
\hline \multirow[t]{2}{*}{7.} & Administrasi Pendidikan (ADPEND) & 5 \\
\hline & $\begin{array}{c}\text { Jumlah } \\
\end{array}$ & 36 \\
\hline
\end{tabular}


Untuk menjaring data yang dibutuhkan dalam penelitian ini digunakan instrument dalam bentuk angket. Angket digunakan untuk mengungkapkan pengaruh penerapan $\mathrm{CEt}$ melalui outbond training sebelum dan sesudah perlakukan dalam meningkatkan kejujuran dan integritas mahasiswa. Sebelum angket ini digunakan dalam penelitian terlebih dahulu dilakukan uji validitas (uji coba instrument).

Teknik analisis data yang digunakan yaitu analisis deskriptif. Analisis deskriptif digunakan untuk menggambarkan tingkat kejujuran dan integritas pada mahasiswa Bidik Misi Fakultas Ilmu Pendidikan Universitas Negeri Makassar sebelum dan sesudah perlakuan dengan menggunakan table distribusi frekuensi dan persentase dengan rumus:

$\mathrm{P}=\frac{f}{N} \times 100 \%$

(Tiro, 2004: 242)

Di mana:

P : Persentase

$\mathrm{f} \quad$ : Frekuensi yang dicari persentasenya

$\mathrm{N}$ : Jumlah subjek eksperimen

Guna memperoleh gambaran umum tentang tingkat kejujuran dan integritas mahasiswa sebelum dan setelah perlakuan, maka dilakukan perhitungan rata-rata kejujuran dan integritas berdasarkan hasil angket penelitian, dengan rumus:

$\mathrm{Me}=\frac{\sum X i}{n}($ Sugiyono, 2004: 43)

Di mana :

Me : Mean (rata-rata)

$\sum \quad:$ Jumlah

$\mathrm{Xi} \quad$ : Nilai $\mathrm{X}$ ke i sampai ke $\mathrm{n}$
$\mathrm{N} \quad$ : Banyaknya subjek

Pengukuran efektivitas penerapan CEt melalui outbond training untuk peningkatan kejujuran dan integritas mahasiswa dilakukan dengan menguji perbedaan dua rata-rata (uji-t) melalui analisis data tingkat kejujuran dan integritas mahasiswa sebelum dan setelah mengikuti CEt melalui outbond training.

Teknik pengujian efektivitas dilakukan dengan menggunakan bantuan software statistical product and service solution (SPSS).

\section{HASIL DAN PEMBAHASAN}

Gambaran tingkat kejujuran dan integritas mahasiswa bidik misi sebelum dan sesudah diberikan character education training (CEt) melalui outbound Gambaran tingkat kejujuran dan integritas mahasiswa bidik misi sebelum dan sesudah perlakuan, secara rinci diuraikan dalam Tabel 4.1 berikut.

Tabel 4.1. Tingkat kejujuran dan integritas mahasiswa bidik misi

\begin{tabular}{c|c|c|c|c|c}
\hline \multirow{2}{*}{ INTERVAL } & \multirow{2}{*}{ KATEGORI } & \multicolumn{2}{|c|}{ Pretest } & \multicolumn{2}{c}{ Posttest } \\
\cline { 3 - 6 } & & Frekuensi & Persentase & \multirow{2}{*}{ Frekuensi } & Persentase \\
\hline $111-129$ & Sangat Tinggi & 0 & 0 & 8 & $22 \%$ \\
\hline $82-100$ & Tinggi & 0 & 0 & 26 & $72 \%$ \\
\hline $63-81$ & Sedang & 26 & $72 \%$ & 2 & $6 \%$ \\
\hline $44-62$ & Rendah & 10 & $28 \%$ & 0 & 0 \\
\hline
\end{tabular}




\begin{tabular}{c|c|c|c|c|c}
\hline $25-43$ & Sangat Rendah & 0 & 0 & 0 & 0 \\
\hline Jumlah & 36 & $100 \%$ & 36 & $100 \%$ \\
\hline
\end{tabular}

Gambaran tingkat kejujuran dan integritas mahasiswa bidik misi sebelum pemberian perlakuan yaitu sebagian besar mahasiswa berada pada kategori sedang atau sebesar $72 \%$ dan selebihnya berda pada kategori rendah atau 28\%. Berdasarkan data tersebut, gambaran tingkat kejujuran dan integritas mahasiswa bidik misi sebelum pemberian perlakuan masih berada pada kategori yang belum cukup memadai. Data di atas menunjukkan mahasiswa bidik misi FIP UNM sebelum diberikan perlakuan masih perlu meningkatkan karakter kejujuran dan integritas dalam dirinya.

Adapun gambaran tingkat kejujuran dan integritas mahasiswa bidik misi setelah pemberian perlakuan yaitu sebagian kecil mahasiswa masih berada pada kategori sedang atau $6 \%$, sebagian besar mahasiswa berada pada kategori tinggi atau sebesar $72 \%$, dan pada kategori tinggi sebesar $22 \%$.

\section{Gambaran Efektivitas Character} Education Training (CEt) Melalui Outbound Training untuk Peningkatan Kejujuran dan Integritas Mahasiswa Bidik Misi FIP UNM Pengujian efektivitas Character Education Training (CEt) melalui Outbound Training untuk peningkatan kejujuran dan integritas mahasiswa bidik misi dilakukan dengan uji statistik. Data yang diperoleh dari uji coba program, kemudian dianalisis dengan mempergunakan uji-t yang hasilnya dapat dideskripsikan sebagai berikut.

Uji statistik dilakukan untuk menguji efektivitas CEt dengan cara membandingkan keadaan awal (pretest) dan keadaan akhir (posttest) dan menguji hipotesis apakah terdapat perubahan positif yang signifikan terhadap tingkat keberhasilan peningkatan kejujuran dan integritas Mahasiswa Bidik Misi FIP UNM setelah mengikuti Character Education Training (CEt) melalui Outbound Training, dengan mengacu pada hipotesis.

$\mathrm{H}_{\mathrm{o}}: \mu_{\text {pretest }}=\mu_{\text {posttest }}$

Character Education Training (CEt) melalui Outbound Training tidak efektif untuk peningkatan kejujuran dan integritas mahasiswa Bidik Misi FIP UNM sebelum dan setelah mengikuti CEt.

$\mathrm{H}_{1}: \mu_{\text {pretest }}<$ posttest

Character Education Training (CEt) melalui Outbound Training efektif untuk peningkatan kejujuran dan integritas mahasiswa Bidik Misi FIP UNM setelah mengikuti CEt lebih baik dibandingkan sebelum perlakuan

Adapun hasil pengujian statistiknya sebagai berikut.

Tabel 4.2. hasil pengujian statistik

\begin{tabular}{c|c|c|c|c}
\hline & $\mathrm{N}$ & Mean & Std. Deviation & Std. Error Mean \\
\hline Pretest & 36 & 66,4444 & 9,72903 & 1,62150 \\
Posttest & 36 & 96,6389 & 6,41049 & 1,06842 \\
\hline
\end{tabular}

Hasil skor rata-rata posttest menunjukkan hasil yang lebih tinggi dibandingkan pretest dengan kata lain hasil skor rata-rata posttest mengalami peningkatan dibandingkan pretest. Hal ini menunjukkan
Character Education Training (CEt) melalui Outbound Training efektif untuk peningkatan kejujuran dan integritas mahasiswa Bidik Misi FIP UNM. 
Tabel 4.3 Perbedaan nilai uji-t tingkat kejujuran dan integritas mahasiswa bidik misi sebelum dan setelah diberikan character education training (CEt) melalui outbound

\begin{tabular}{|c|c|c|c|c|c|c|}
\hline & \multicolumn{6}{|c|}{ Test Value $=0$} \\
\hline & \multirow[b]{2}{*}{$\mathrm{t}$} & \multirow[b]{2}{*}{$\mathrm{df}$} & \multirow{2}{*}{$\begin{array}{l}\text { Sig. (2- } \\
\text { tailed) }\end{array}$} & \multirow{2}{*}{$\begin{array}{c}\text { Mean } \\
\text { Difference }\end{array}$} & \multicolumn{2}{|c|}{$\begin{array}{c}95 \% \text { Confidence Interval } \\
\text { of the Difference }\end{array}$} \\
\hline & & & & & Lower & Upper \\
\hline Pretest & 40,977 & 35 &, 000 & 66,44444 & 63,1526 & 69,7363 \\
\hline Posttest & 90,451 & 35 & ,000 & 96,63889 & 94,4699 & 98,8079 \\
\hline
\end{tabular}

Hasil uji t seperti tabel 4.3 pemberian CET sebelum perlakuan sebesar $(\mathrm{t}$ hitung $=$ $40,977, \mathrm{p}=0.000<0.05)$ pada df $35(\mathrm{n}-1,36-1)$ dan setelah perlakuan sebesar $(\mathrm{t}$ hitung $=90,451$ $\mathrm{p}=0.000<0.05)$ pada df $35(\mathrm{n}-1.36-1)$. Dengan demikian, $\mathrm{t}$ hitung sebelum perlakuan $=40,977$ dan setelah perlakuan $=90,451>$ dari $\mathrm{t}$ tabel $=$ 1,697. Dengan kata lain bahwa terjadi peningkatan kejujuran dan integritas setelah diberikan CEt melalui outbond. Artinya bahwa CEt dapat meningkatkan kejujuran dan integritas mahasiswa Bidik Misi FIP UNM.

Berdasarkan analisis data di atas, Character Education Training (CEt) melalui Outbound Training dapat menjadi cara untuk dapat meningkatkan kejujuran dan integritas mahasiswa.

Outbound Training mempunyai arti kegiatan di luar ruangan yang sangat bermanfaat bagi mahasiswa karena mengandung unsur edukasi yang dapat membentuk karakter seseorang. Pembentukan karakter mahasiswa merupakan hal yang sangat penting selaku peserta didik. Melalui permainan-permainan ringan yang menarik, peserta dihadapkan pada suatu tantangan untuk dipecahkan secara bersama-sama dengan sejenak melepaskan atribut masing-masing. Sehingga diharapkan tercipta suasana keakraban, kebersamaan serta kerjasama tim yang nantinya bermanfaat dalam mengatasi permasalahan yang lebih besar (Umar:2011).

Mengembangkan berbagai potensi dapat dilakukan melalui belajar yang berbasis outdoor. Metode outdoor dapat meningkatkan kebersamaan, kesetiakawanan pelajar, serta dapat memberikan inspirasi kepada pembelajar. Hal ini merupakan nilai-nilai karakter pada potensi individu.
Zulkarnain (2013: 206) mengungkapkan bahwa tujuan outbound bermacammacam sesuai dengan subjek dan objeknya atau tergantung dari tujuan yang akan dicapai serta sasarannya. Outbound dapat membentuk karakter mahasiswa untuk menjadi mahasiswa yang jujur dan berintegritas.

Tujuan utama kegiatan pelaksanaan outbound training adalah melatih para peserta untuk mampu menyesuaikan diri dengan perubahan yang ada dengan membentuk sikap professionalisme para peserta yang didasarkan pada perubahan dan perkembangan karakter termasuk didalamnya mengembangkan perilaku jujur dan integritas, komitmen serta kinerja yang diharapkan akan semakin lebih baik.

Metode outbound merupakan metode yang paling efektif dalam mengakomodasi/kebutuhan tuntutan terhadap hasil suatu pelatihan. metode ini efektif dalam membangun pemahaman terhadap suatu konsep dan membangun prilaku karakter individu. Karakter akan tertanam dan akan menjadi pribadi individu yang lebih baik.

\section{SIMPULAN DAN SARAN}

Hasil penelitian mengenai Character Education Training (CEt) melalui outbound training untuk peningkatan kejujuran dan integritas mahasiswa bidik misi FIP UNM, dapat disimpulkan yaitu: tingkat kejujuran dan integritas mahasiswa bidik misi FIP UNM, berdasarkan hasil pretest atau sebelum diberikan perlakuan menunjukkan sebagian besar mahasiswa berada pada kategori sedang dan selebihnya berda pada kategori rendah atau belum cukup memadai dan perlu untuk ditingkatkan. Adapun hasil posttest atau setelah pemberian perlakuan, sebagian kecil mahasiswa 
masih memiliki tingkat kejujuran dan integritas pada kategori sedang namun sebagian besar berada pada kategori tinggi. Hal ini menunjukkan Character Education Training (CEt) melalui outbound training efektif untuk peningkatan kejujuran dan integritas mahasiswa bidik misi FIP UNM.

Dari penelitian ini disarankan agar kegiatan aoutbond bagi mahasiswa yang umum atau reguler juga diberikan tidak hanya kepda mahasiswa penerima beasiswa bidikmisi. Pimpinan fakutas dan jurusan dapat memperhatikan kebutuhan perkembangan mahasiswa terutama dari segi kejujuran dan integritasnya. Dan bagi peneliti dapat menjadi bahan referensi untuk penelitian selanjutnya.

\section{DAFTAR RUJUKAN}

Ancok, J. (2013). Outbound Management Training: Aplikasi Ilmu Perilaku dalam Pengembangan Sumber Daya Manusia. Yogyakarta: UII Press.

Al-Qur'an \& Terjemahan. Bandung: PT. Sygma Examedia Arkanleema.

Arikunto, S. (2002). Prosedur Penelitian Pendekatan Problem. Jakarta: RT. Rineka Cipta.

Aryani, F. (2014). Bimbingan Belajar, Cara Efektif Menulis Karya Ilmiah Tanpa Plagiat. Makassar. Edukasi Mitra Grafika.

Bakhtiar, M. I. (2015). Pengembangan Video Ice Breaking Sebagai Media Bimbingan Konseling. Jurnal Psikologi Pendidikan Dan Konseling, 1(2), 150-163. Retrieved from http://ojs.unm.ac.id/index.php/JPPK/ article/view/1816

Hadi, S. (2007). Metodogi Research: Jilid 2. Yogyakarta: Andi

Sugiyono. (2004). Statistik untuk Peneltian. Bandung: Alfabeta.

Sugiyono.(2015). Metode Penelitian Pendidikan: Pendekatan Kuantitatif, Kualitatif, dan R\&D. Bandung: Alfabeta.
Susilo. (2005). Outbound itu Menyesatkan?. Jakarta: Budi Cendekia.

Tim Pengembang SPMI-PT. 2010. Sistem Penjaminan Mutu Internal Perguruan Tinggi. Direktorat Pendidikan, Direktorat Jendral Pendidikan Tinggi.

Tiro, A. (2004). Dasar-dasar Statistik. Ujung Pandang: UNM.

Umar, T. (2011). Pengaruh Outbond Training terhadap Peningkatan Rasa Percaya Diri Kepemimpinan dan Kerjasama Tim. Jurnal Ilmiah SPIRIT. ISSN; 1411-8319 Vol. 11 No. 3 Tahun 2011.

Widia. (2014). Peran Mahasiswa dalam Meningkatkan Mutu Pendidikan (online) www.kompasiana.com.

Zulkarnain, W. (2013). Dinamika Kelompok: Latihan Kepemimpinan Pendidikan. Jakarta: Bumi Aksara. 